\title{
Efetividade do direito fundamental a razoável duração do processo ${ }^{1}$
}

\author{
Roberto Martinato ${ }^{2}$ \\ Profa. Dra. Marlene Kempfer Bassoli ${ }^{3}$
}

\begin{abstract}
Resumo
Analisa meios e limites de efetivação da aplicabilidade imediata do novel inciso LXXVIII do art. 50 da Constituição Federal - direito à "razoável duração do processo" -, de forma a dotá-lo da eficácia possível frente à morosidade crônica verificada na tramitação dos processos judiciais no Brasil, sob o aspecto da indenização estatal originária da responsabilidade do Estado. Para tanto, levanta as dificuldades mais relevantes na aplicação imediata de tal preceito - inserto no rol dos direitos fundamentais -, face à difícil incumbência de se estabelecer objetivamente o que seria razoável na duração do processo judicial. Com esse norte, socorre-se no princípio da proporcionalidade para obter um caminho teoricamente viável para a realização do novo direito fundamental.
\end{abstract}

Palavras Chave: Razoável duração do processo; Princípio da proporcionalidade.

\section{Introdução}

É indiscutível a existência, particularmente no Brasil, do problema da excessiva morosidade na prestação jurisdicional.

Muito embora a Constituição Federal preceitue em seu Art. 5ำ, inciso XXXV, que "a lei não excluirá da apreciação do Poder Judiciário lesão ou ameaça a direito", assegurando, assim, a todos o acesso ao Poder Judiciário para solução dos conflitos próprios da convivência social, sabe-se, também, que esse acesso à justiça, garantido por tal preceito fundamental, não se concretiza com o simples acolhimento da petição inicial no Judiciário, mas sim com a efetiva prestação jurisdicional, a qual possa prover ao jurisdicionado o bem da vida que lhe pertença de direito.

Da delonga na entrega da prestação jurisdicional que assegure o bem da vida a quem de direito, podem resultar danos materiais e/ou morais injustos e irreversíveis. Danos

1 Este ensaio teve por referência Trabalho de Conclusão de Curso apresentado ao Curso de Direito da Universidade Estadual de Londrina, de autoria do primeiro sob a orientação da segunda.

2 Aluno do 50 ano de Direito da Universidade Estadual de Londrina.

3 Doutora em Direito do Estado - Direito Tributário pela PUC-SP. Professora de Direito Tributário na graduação do Curso de Direito da Universidade Estadual de Londrina e dos programas de Mestrado em Direito da Universidade Estadual de Londrina e da Universidade de Marília. 
estes que, em sendo suportados pelo jurisdicionado, podem configurar flagrante convivência do direito com a injustiça, fato que não se deve aceitar cômoda e confortavelmente.

Considerando, ainda, que a Emenda Constitucional no 45/2004 incluiu dentre os direitos fundamentais o correspondente à razoável duração do processo, e que o $\S 1$ 으 do Art. 50 da Lei Maior preceitua que "as normas definidoras dos direitos e garantias fundamentais têm aplicação imediata", torna-se inevitável a indagação de como dar aplicabilidade imediata a esse novo direito fundamental, frente à lentidão crônica do Poder Judiciário.

Nesse contexto, o presente artigo tem como escopo traçar algumas considerações acerca de eventuais caminhos que possam, de alguma forma, viabilizar a eficácia do direito fundamental à razoável duração do processo judicial.

\section{0 acesso à justiça como direito subjetivo fundamental}

Como já mencionado, a Constituição Federal de 1988 assegura a todos o acesso ao Judiciário. Esta previsão contempla o cidadão com o direito subjetivo fundamental à jurisdição, conforme explana, nesse sentido, a profa. Carmem Lúcia Antunes Rocha, citada pelo Prof. José Augusto Delgado (2005), afirmando que "o direito à jurisdição é o direito público subjetivo constitucionalmente assegurado ao cidadão de exigir do Estado a prestação daquela atividade". Acrescenta, ainda, que "a jurisdição é, então, de uma parte, direito fundamental do cidadão, e, de outra, dever do Estado".

Com efeito, uma simples leitura do texto constitucional mostra-se hábil a eliminar qualquer dúvida quanto à garantia conferida ao cidadão de ter acesso aos órgãos prestadores da jurisdição. No entanto, o acesso à justiça não se completa, obviamente, com o recebimento da petição inicial pelo órgão jurisdicional. Este ato constitui apenas a primeira fase. Deduzida a questão em juízo, fica-se a espera de uma resposta estatal eficiente, pronta e eficaz, de forma a resguardar e finalmente concretizar o direito pelo qual se luta.

Atento aos diversos problemas que a morosidade na prestação jurisdicional acarreta injustamente aos jurisdicionados, o legislador, por meio da Emenda Constitucional no 45/2004 - a qual teve como principal escopo o de conferir maior celeridade à referida prestação -, fez incluir no rol dos direitos e garantias individuais e coletivos o relativo à "razoável duração do processo" e aos "meios que garantam a celeridade de sua tramitação", 
dando nova amplitude e maior densidade ao direito subjetivo pré-existente de acesso à justiça.

Faz-se necessária, no entanto, uma análise mais acurada acerca dos resultados práticos que poderão advir da positivação desse novo direito fundamental, já que, por estar expressado de forma vaga, deixa uma margem por demais grande para sua interpretação e aplicação, dando azo ao risco de se tornar letra morta em virtude de eventual concretização inexpressiva. Nesse sentido, Paulo Bonavides (2004, p. 185), comentando os "direitos que obrigam o poder a um status activus de ordem material, ou seja, a concretizar uma liberdade real que transcende a liberdade jurídica", alerta para o fato de não raro apresentarem "alcance indefinido e extensão polêmica", porque "vazados em proposições demasiado abrangentes, genéricas e vagas, de teor programático, com o flanco aberto às evasivas dos intérpretes e dos aplicadores". Acredita-se ser real tal risco se considerado o vago sentido que os termos razoável duração do processo traduzem.

\subsection{Conceito de direito fundamental}

Num sentido mais restrito, mais específico e mais normativo, entende-se por direitos fundamentais, segundo Paulo Bonavides (2004, p. 560-561), apoiado em Konrad Hesse, "aqueles direitos que o direito vigente qualifica como tais", e numa acepção mais lata, aqueles direitos que buscam "criar e manter os pressupostos elementares de uma vida na liberdade e na dignidade humana".

Na seqüência, Bonavides menciona alguns critérios estabelecidos por Carl Schmitt para caracterizar os direitos fundamentais. Nesse toque, do ponto de vista formal dessa caracterização, ressalta dois aspectos, quais sejam: pelo primeiro consigna que seriam "direitos fundamentais todos os direitos ou garantias nomeadas e especificadas no instrumento constitucional"; e pelo segundo, que podem ser designados por direitos fundamentais "aqueles direitos que receberam da Constituição um grau mais elevado de garantia ou de segurança", sendo estes, por conseguinte, imutáveis ou de difícil mudança, a saber, "direitos unicamente alteráveis mediante lei de emenda à Constituição". Já no que tange ao prisma material, afirma aquele Autor que os direitos fundamentais "variam conforme a ideologia, a modalidade de Estado, a espécie de valores e princípios que a 
Constituição consagra". E, finalizando, que "cada Estado tem seus direitos fundamentais específicos".

No entanto, considerando que toda a gama de direitos fundamentais conquistados por um determinado povo constitui fruto de lutas travadas ao longo de sua história, Paulo Bonavides (2004, p. 563-571) ensina que tais conquistas podem ser divididas em gerações, da seguinte forma: a) os de primeira geração "são os direitos da liberdade, os primeiros a constarem do instrumento normativo constitucional, a saber, os direitos civis e políticos, [...]"; b) os de segunda geração, que dominaram o século XX e têm como sustentáculo o princípio da igualdade, "são os direitos sociais, culturais e econômicos bem como os direitos coletivos ou de coletividades, introduzidos no constitucionalismo das distintas formas de Estado social $[. . .]^{\prime \prime}$; c) os direitos fundamentais de terceira geração, alicerçados no princípio da fraternidade, "têm primeiro por destinatário o gênero humano mesmo, num momento expressivo de sua afirmação como valor supremo em termos de existencialidade concreta" e são, segundo Bonavides com apoio em Vasak e outros: o direito ao desenvolvimento, o direito à paz, o direito ao meio ambiente, o direito de propriedade sobre o patrimônio comum da humanidade e o direito de comunicação; d) por sua vez, os direitos fundamentais de quarta geração, que, conforme salienta o referido Autor, "correspondem à derradeira fase de institucionalização do Estado social [...]", são o direito à democracia, o direito à informação e o direito ao pluralismo.

Cita-se, finalmente, Walber de Moura Agra (2002, p. 135), para quem "os direitos fundamentais assinalam um dos traços mais marcantes do constitucionalismo moderno, em que eles são tomados como direitos invioláveis dos homens, que de forma alguma podem ser suplantados", o que vem realçar a responsabilidade imposta a todos os operadores do direito em buscar sempre a eficácia ótima de todas as normas definidoras de direitos fundamentais.

\subsection{A efetividade do direito fundamental à razoável duração do processo}

Para Konrad Hesse (1991, p. 14-15), “a norma constitucional não tem existência autônoma em face da realidade". Por conseguinte, ressalta que a pretensão de eficácia de determinada norma depende das condições naturais, técnicas, econômicas, e sociais. Leciona, assim, que a desejada eficácia da norma jurídica somente será realizada se levar em 
conta essas condições, além do "substrato espiritual que se consubstancia num determinado povo, isto é, as concepções sociais concretas e o baldrame axiológico que influenciam decisivamente a conformação, o entendimento e a autoridade das proposições normativas".

À luz de tal entendimento, pode-se correr o risco em dizer que o novo direito fundamental sob enfoque está impregnado de legitimidade, já que não se duvida do anseio geral do povo em contar com um processo mais célere e imbuído da capacidade de prover, em tempo razoável, o bem da vida a quem de direito. Portanto, conta o preceito normativo com o "substrato espiritual" e com o "baldrame axiológico" necessários - mas não suficientes - à sua eficácia, conforme ressalta Konrad Hesse. Contudo, não há tanta certeza quanto à existência das condições técnicas e econômicas favoráveis à correspondente concretização, condições estas realçadas, também, como necessárias à pretensão de eficácia da norma jurídica constitucional.

Considerando-se que para Lenio Luiz Streck (2004, p. 39) "a noção de Estado Democrático de Direito está [...] indissociavelmente ligado à realização dos direitos fundamentais", pode-se afirmar então, como corolário, que a existência de direito fundamental legitimamente expressado na Constituição e não devidamente concretizado no panorama real - desde que dentro dos limites da concretização possível, fixados com ponderação, inclusive, da concorrência entre os diversos direitos de mesmo patamar constitui verdadeira anomalia no Estado Democrático de Direito.

Todavia, não há como deixar de questionar o que seria razoável em termos de duração do processo judicial. Há casos em que a demora mostra-se como verdadeira aberração, chegando a atingir a marca de 10, 15 ou até mais de 20 anos para que o jurisdicionado obtenha a final prestação jurisdicional. Noutros, bem menos tempo. Mas tanto nestes mais breves quanto naqueles mais demorados, qual o tempo de tramitação que poderia ser considerado razoável? Quais os principais fatores ponderáveis na análise dessa razoabilidade? Obviamente, a complexidade da causa seria um deles. Mas, a grande questão que se apresenta é: qual seria o tempo razoável para cada processo judicial em face de sua complexidade e de suas características próprias? Não há dúvida quanto ao caráter essencialmente subjetivo de cada resposta que se possa obter de norte a sul do País. Podese depreender daí, então, que seria necessária a participação do legislador 
infraconstitucional na definição objetiva do que seria razoável nesse tempo de espera, o qual em virtude da excessiva delonga pode causar danos ao jurisdicionado.

Como já expressado, no entanto, o $§ 10$ do Art. 5ㅇ da Carta Magna preceitua que "As normas definidoras dos direitos e garantias fundamentais têm aplicação imediata". Logo, há de ser possível retirar efeitos práticos imediatos de tal dispositivo. Ou não? Manoel Gonçalves Ferreira Filho (1990, p. 268) louva a intenção do legislador constituinte ao dispor tal parágrafo, que era a de tornar efetivos os direitos consagrados na Constituição de 1988, impedindo-os de permanecer como "letra morta", porém reconhece que "o caminho escolhido não é suficiente em si para atender o objetivo colimado". E nesse sentido, conclui "que uma norma constitucional, mesmo a definidora de direitos ou garantias fundamentais, somente pode ser aplicada se for completa".

Analisando os dispositivos constitucionais pelo ângulo da aplicabilidade e da capacidade de produzir efeitos, Regina Maria M. Nery Ferrari (2001, p. 136) ressalta a existência de normas, principalmente no campo dos direitos fundamentais, "que: 1. Não dependem de nenhum tipo de integração legislativa infraconstitucional para incidir; 2 . admitem regulamentação para facilitar seu modus operandi; 3. dependem de norma regulamentadora integrativa, para que estejam aptas a incidir no mundo dos fatos". No que concerne ao direito à razoável duração do processo, qual seria seu correto enquadramento?

Quer parecer que, não obstante se discuta a respeito da necessidade ou não de norma infraconstitucional que venha esclarecer melhor, quiçá de forma objetiva, o que seja razoável em termos de morosidade processual, não se pode negar, desde já, que algumas situações fáticas mostram-se em flagrante desrespeito ao que seria aceitável como razoável duração do processo, ou seja, não há como ignorar a existência de muitos casos, particularmente no judiciário, que escancaram o total descaso por parte dos entes públicos no que concerne à desejada celeridade processual.

Nesses casos, salvo melhor juízo, a regulamentação posterior mostra-se inteiramente prescindível para que o Estado seja responsabilizado pelos danos decorrentes da excessiva morosidade, já que inquestionável a extrapolação de todo e qualquer parâmetro que se pretenda razoável, bem como evidente a omissão do Poder Público em face do seu dever de prestar o serviço jurisdicional. 
Acrescente-se que, conforme ensina Luís Roberto Barroso (2002, p. 80), as normas constitucionais definidoras de direitos proporcionam aos seus beneficiários a inclusão em "situações jurídicas imediatamente desfrutáveis, a serem efetivadas por prestações positivas ou negativas, exigíveis do Estado ou de outro eventual destinatário da norma". Em não sendo cumprido espontaneamente tal dever jurídico, abre-se ao titular do direito lesado a imediata oportunidade para exigir do Estado a intervenção coercitiva no sentido de assegurar, por meio do cumprimento forçado do mandamento normativo, a entrega da prestação pretendida (BARROSO, 2002, p. 84). Evidenciado aí, portanto, o direito de ação previsto no inciso XXXV do art. 5 da Constituição Federal.

Mas, é de se convir que não faria sentido lógico o exercício desse direito de ação junto ao juízo a quo visando celeridade na tramitação de outro processo. E quanto à celeridade deste último? Não sendo satisfatória, abriria oportunidade para nova ação? Se o congestionamento, na maioria das vezes, é apontado como o principal fator de influência na morosidade da tramitação das ações judiciais, essas novas ações visando celeridade nos atos processuais não viriam agravar a situação do judiciário, com a elevação do grau de abarrotamento de feitos? Não parece aceitável tal espécie de ação, mesmo porque o dever de celeridade, como preceito constitucional explicitado no rol dos direitos fundamentais, deve ser observado em cada ação em trâmite, independentemente de requerimento das partes.

Contudo, poder-se-ia, a exemplo do que ocorre na Áustria, na Alemanha e em mais alguns países, questionar junto à Corte competente para "a guarda da Constituição" eventual descumprimento de preceito fundamental, na forma do $\S 1$ o do art. 102 da Lei Maior brasileira, já que assim consigna: "A argüição de descumprimento de preceito fundamental, decorrente desta Constituição será apreciado pelo Supremo Tribunal Federal, na forma da lei". No entanto, a lei no 9.882, de 03 de dezembro de 1999, de papel integrador daquele preceito constitucional, teve o inciso II do parágrafo único do seu art. 1ㅇv vetado pelo Presidente da República, fato este que impossibilitou "a propositura ampla da argüição de descumprimento de preceito fundamental, por qualquer prejudicado, nos termos do recurso de amparo previsto no ordenamento jurídico espanhol e argentino", no dizer de Alexandre de Moraes (TAVARES, 2001, p. 22), que ressalta, assim, a impossibilidade de "acesso direto ao Supremo Tribunal Federal a qualquer pessoa que afirme ter sido 
diretamente lesionada em face do descumprimento de preceitos fundamentais previstos constitucionalmente".

Não obstante a impossibilidade de o cidadão comum, no Brasil, ingressar diretamente junto ao Supremo Tribunal Federal com a argüição de descumprimento de preceito fundamental, não parece restar dúvidas, no entanto, sobre o cabimento de ação indenizatória correspondente aos danos decorrentes da excessiva e inescusável demora na prestação jurisdicional. O nó que ainda se apresenta, e em grande parte devido à imprecisão dos termos empregados no novel inciso LXXVIII do Art. 5 da Constituição Federal, é a definição dos parâmetros necessários à apreciação objetiva do que é ou do que deixa de ser razoável na demora da prestação jurisdicional.

Sabe-se de antemão, como já ressaltado - de acordo com texto de Konrad Hesse (1991, p. 14-15), que os problemas enfrentados na convivência social nem sempre podem ser resolvidos pela simples inclusão no ordenamento jurídico de normas que pretendam solucioná-los. É preciso mais, para se concretizar a solução pretendida. Com efeito, faz-se necessário um sério estudo sobre a exeqüibilidade do preceito com o qual se busca resolver o problema detectado. Portanto, não há como ignorar a realidade e as possibilidades concretas de sua alteração. Sem tais considerações, corre-se o risco de se incluir no ordenamento jurídico preceitos sem eficácia, sem efetividade, sem a mínima possibilidade de se converter em resultados concretos e modificadores da situação real.

No que concerne ao direito à razoável duração do processo, talvez tenha muito dessa impossibilidade de alteração imediata da realidade, mesmo porque se sabe da difícil situação do Poder Judiciário brasileiro, quer seja pela "falta de aparelhamento adequado" quer seja pela "sobrecarga de trabalho a que estão submetidos juízes e auxiliares" (LOUREIRO FILHO, 2005, p. 217-218).

Contudo, muito embora expressado em termos imprecisos, acredita-se que o referido inciso LXXVIII tenha certamente reforçado de forma significativa a idéia de que são inaceitáveis os patamares de morosidade atualmente verificados na prestação jurisdicional brasileira, e que algo é preciso ser feito, e já, para ao menos amenizar o problema. Em sendo assim, mesmo que não tenha o condão de garantir de imediato a solução completa do problema, atribuiu aos preceitos constitucionais a densidade suficiente ao menos a tornar certa a responsabilização do Estado por danos causados pela excessiva morosidade da 
justiça, já que constitui inquestionável dever do Poder Público a prestação jurisdicional em tempo razoável.

Nesse sentido, Loureiro Filho (2005, p. 212) expõe que "malgrado as justificativas de má remuneração, de aparelhamento inadequado, de uma legislação a possibilitar recursos protelatórios e da falta de quadros, a demora excessiva na prestação jurisdicional conduz inegavelmente ao dano injusto" e acrescenta que por vezes pode "constituir verdadeira forma de denegação de justiça".

Prossegue o citado Autor expondo que "uma vez caracterizada a prestação jurisdicional como direito fundamental assegurado pelo Estado, a demora em sua prestação vem a configurar, de forma manifesta, atividade pública imperfeita", e acrescenta que são irrelevantes, para o jurisdicionado que vem pleitear a respectiva indenização por danos sofridos em decorrência da citada imperfeição da atividade judiciária, "os motivos determinantes da delonga injustificável, indolência do juiz, mau aparelhamento da máquina, falta de quadros [...]", reconhecendo, finalmente, que apenas o comportamento da parte que se acha lesada em decorrência da delonga do processo poderia constituir, em última análise, justificativa válida a excluir a responsabilidade do Estado pela demora excessiva na prestação jurisdicional (vide 3.2).

E neste ponto surge outro nó: são notórios os mais diversos danos sofridos pelos jurisdicionados - patrimoniais e/ou morais - que têm por causa a excessiva demora na prestação jurisdicional. Essa demora na grande maioria dos casos mostra-se absolutamente inescusável, senão pelas diversas deficiências do próprio aparato judiciário. Logo, em se considerando a certeza - ao menos doutrinária - da responsabilidade do Estado por tais danos ( $§ 60$ do Art. 37 da Constituição Federal) e, por conseguinte, da obrigação de custear a correspondente indenização aos respectivos jurisdicionados, questiona-se: como fazer frente à monstruosa despesa que certamente daí decorreria, já que, como se sabe, os orçamentos da União e das Unidades da Federação são elaborados com base em recursos financeiros limitados?

Nesse aspecto, Paulo Bonavides (2000, p. 545) acena com a chama que talvez tenha o condão de solucionar o dilema, quando observa que em virtude da peculiaridade imanente à estrutura normativa dos direitos fundamentais, sua hermenêutica exige, segundo Koch, "decisão de prioridade" ou primazia, ao se deparar, por exemplo, com situações de conflito 
entre direitos fundamentais ou em situações tais que, em face da escassez de recursos materiais disponíveis ao Estado, a realização de um determinado direito fundamental impossibilite a realização completa de outro. Nesses casos, ressalta o Autor, para que se possa dar a máxima eficácia possível aos múltiplos direitos fundamentais, mostrase necessária a aplicação do princípio da proporcionalidade.

\section{0 socorro provido pelo princípio da proporcionalidade}

O princípio da proporcionalidade, também tratado pelos alemães como proibição de excesso e pelos americanos como razoabilidade - muito embora Celso Antônio Bandeira de Mello (1993, p. 56) entenda que "em rigor, o princípio da proporcionalidade não é senão faceta do princípio da razoabilidade" -, presta-se como valioso instrumento de interpretação, capaz de possibilitar solução conciliatória toda vez que ocorre antagonismo entre direitos fundamentais (BARROS, 2003, p. 74; BONAVIDES, 2000, p. 386-387).

Paulo Bonavides (2000, p. 387), apoiado em Georg Ress, ressalta, ainda, que "o princípio da proporcionalidade, enquanto máxima de interpretação, não representa nenhum critério material, ou seja, substantivo, de decisão, mas serve tão-somente para estabelecer, como diretiva procedimental", o caminho através do qual se possa chegar à decisão material justa, que solucione o caso concreto e específico e ao mesmo tempo confira "aos bens jurídicos conflitantes uma eficácia ótima".

A doutrina alemã apresenta três sub-princípios que considera como integrantes do princípio da proporcionalidade, quais sejam: o da adequação, o da necessidade e o da proporcionalidade em sentido estrito, "os quais, em conjunto, dão-lhe a densidade indispensável para alcançar a funcionalidade pretendida pelos operadores do direito". Quanto ao princípio da adequação ou da idoneidade, como se depreende do próprio termo, significa analisar a correta adequação da medida adotada para se atingir o fim desejado. No que toca ao princípio da necessidade ou da exigibilidade, significa dizer que é o pressuposto "de que a medida restritiva seja indispensável para a conservação do próprio ou de outro direito fundamental e que não possa ser substituída por outra igualmente eficaz, mas menos gravosa". E, finalmente, no que concerne ao princípio da proporcionalidade em sentido estrito, centrase na justa carga representada pelo ônus imposto ao atingido pela medida restritiva de direito, ou seja, mesmo quando o juiz "considera adequada a relação entre 64

ReVista de Direito Público, Londrina, v. 1, N. 2, P. 55-74, MAIO/Ago. 2006. 
determinada restrição e o fim a que se destina, ou mesmo quando reconhece a inexistência de outro meio menos gravoso que pudesse conduzir ao mesmo resultado", ainda assim impõe-se como necessária a preocupação em se obter com a medida adotada uma justa distribuição de ônus (BARROS, 2003, p. 84-87).

No que concerne ao direito fundamental à razoável duração do processo, respeitados os direitos ao devido processo legal, ao contraditório e à ampla defesa, seria difícil imaginar uma situação conflituosa entre aquele e os demais direitos fundamentais. Contudo, pode-se vislumbrar problema quando colocada sob análise a questão da possibilidade prática de se realizar plena e simultaneamente mais de um direito fundamental, mormente quando estas realizações dependam de recursos materiais escassos e insuficientes, como, por exemplo, os recursos financeiros que compõem os orçamentos estatais.

Assim, considerando uma possível não atuação do legislador infraconstitucional no sentido de se fixar parâmetros objetivos da razoabilidade da demora processual, pode-se se afirmar que quaisquer que sejam as interpretações e aplicações que venham se dar, certamente refletirão um determinado grau de restrição ao referido direito fundamental. Essa limitação, no dizer de Suzana de Toledo Barros (2003, p. 162), pode ser classificada como uma restrição imanente ou implícita na própria norma, ou seja, inserida nos "limites constitucionais não escritos". E conclui a referida Autora (2003, p. 171): "os limites imanentes decorreriam da idéia de não-perturbação: cada direito seria limitado pela existência de outros direitos, evitando-se o abuso e o prejuízo dos outros".

Mas como iniciar a aplicação efetiva do direito fundamental à razoável duração do processo? Quais os parâmetros iniciais?

Já se viu, com base em Konrad Hesse (1991, p. 14-15), que a realização dos direitos constitucionalmente garantidos depende das reais condições "naturais, técnicas, econômicas, e sociais", além da legitimidade do processo de positivação. Depreende-se daí, então, que a simples inclusão do direito fundamental à razoável duração do processo no Texto Constitucional não possui o condão de garantir a correspondente eficácia imediata, pois não é, em absoluto, fator suficiente em si para tornar céleres todos os processos judiciais existentes. Mas pode sim constituir elemento decisivo para se impor ao Estado, de 
forma inequívoca, a responsabilização pelo ressarcimento dos danos injustamente sofridos pelos jurisdicionados, decorrentes da excessiva e inescusável morosidade da justiça.

Entretanto, ainda assim, quais danos causados pela morosidade da prestação jurisdicional poderiam ser, inicialmente, passíveis de indenização pelo Estado? Qual o limite, ao menos em um primeiro momento, das indenizações da espécie suportáveis pelo Estado? Sabe-se, de antemão, da impossibilidade financeira do Estado para fazer frente a essas indenizações se todos acorressem aos seus direitos contemporaneamente. Sabe-se, também, da necessidade de se dar igual tratamento a todas as situações semelhantes.

Entende-se que a questão já não está relacionada à existência ou não do direito do cidadão em ser indenizado pelos danos materiais e/ou morais decorrentes da excessiva e inescusável demora na prestação jurisdicional, pois este direito está, a despeito do posicionamento contrário da jurisprudência pátria, claramente previsto na Constituição Federal (Art. 50, LXXVIII, e Art. 37, § 60), mas está sim centrada, ao menos hodiernamente, nas possibilidades materiais do Estado em fazer frente à satisfação de tal direito fundamental a todos aqueles que venham nesse sentido requerer.

Sabe-se que não existe hierarquia entre os diversos direitos fundamentais contemplados na Constituição, mas estes se sobressaem uns em restrição a outros de conformidade com as circunstâncias fáticas que possam autorizar determinadas supremacias ocasionais, não configurando com isso nenhuma antinomia.

Persistindo nesse raciocínio e considerando a morosidade crônica dos processos judiciais no Brasil, pode-se deduzir que, em se dando plena e imediata aplicabilidade ao direito fundamental à razoável duração do processo, por meio da realização de indenizações devidas aos jurisdicionados que em face da delonga na prestação jurisdicional tenham suportado danos injustos, certamente se estaria restringindo a realização de outros direitos fundamentais, tais como o direito à educação, à saúde, à segurança pública, e outros, para os quais indubitavelmente não restariam recursos financeiros suficientes para o mínimo atendimento estatal.

Vislumbra-se, então, que se há alguma possibilidade da referida norma de direitos fundamentais ser justa e efetivamente aplicada no dia a dia dos jurisdicionados, esta justeza e eficácia serão tanto mais certas quanto maior for o auxílio prestado pelo princípio da proporcionalidade, porque se acredita que este será, se já não o é, o material lubrificante 
imprescindível ao perfeito funcionamento da engrenagem sistêmica de aplicação de toda a gama de direitos fundamentais plasmada em nossa Carta Maior.

\subsection{Proposições à aplicabilidade imediata do direito fundamental à razoável duração do processo}

A não ser que o legislador infraconstitucional - orientado pelo princípio $d a$ proporcionalidade - elabore uma lei que contenha de forma objetiva o que seja e o que deixa de ser razoável na duração do trâmite processual no Poder Judiciário, é de se presumir que os magistrados terão muito que tatear, mormente de início - e se valendo também do imprescindível princípio supramencionado -, para dar efetividade à aplicabilidade imediata do novo direito fundamental à razoável duração do processo.

Todavia, independentemente da ação nesse sentido do legislador infraconstitucional, não se pode ignorar o preceito constitucional contido no § 1을 do Art. 5으, que garante a aplicação imediata às normas definidoras dos direitos e garantias fundamentais.

Dessa maneira, com o intuito de se esboçar algum mecanismo eficaz na realização de tal direito fundamental, acredita-se que todo o universo das ações submetidas ao Poder Judiciário possa ficar, em um primeiro momento, dividido em três zonas distintas. A primeira e a última apresentando menor dimensão, enquanto a zona intermediária seria caracterizada por uma faixa bem mais ampla. Esta zona intermediária - à qual se poderia chamar de grande zona cinzenta - conteria todos os processos em trâmite sobre os quais não se pudesse afirmar com segurança, em face do princípio da proporcionalidade, que a demora na tramitação seja suficiente a justificar indenização de eventuais danos dela decorrentes. Importante frisar que esta análise deve ser feita não com base no direito que todo indivíduo tem assegurado pela Constituição, em contar com a razoável duração do processo, mas sim com vistas às possibilidades materiais apresentadas pelo Estado, em determinado momento, de realizar esse direito fundamental e também dar uma efetividade otimizada aos demais direitos de mesmo escalão.

Quanto à primeira zona, conteria todos os processos sobre os quais não pairassem dúvida alguma quanto à razoabilidade do tempo de duração. 
A última zona, de maneira oposta à primeira, traria em seu bojo os processos cuja morosidade na tramitação tenha extrapolado todas as medidas do razoável. Nos quais apareça tão nítida a inescusável demora, que não se possa aventar qualquer sombra de dúvida quanto à sua inadmissibilidade e, por conseguinte, não se possa negar justa indenização ao jurisdicionado que em função da referida delonga tenha sofrido algum dano, seja de ordem patrimonial ou não. Quanto a estes, o magistrado não denegaria o reconhecimento da responsabilidade do Estado e o respectivo ressarcimento ao jurisdicionado atingido. Nessa aplicação, o magistrado conjugaria os valores abstratos positivados na Constituição com a previsão da realização possível em face das reais condições materiais apresentadas pelo Estado, sempre se valendo do indispensável princípio da proporcionalidade.

Há que se frisar aqui, que a análise das possibilidades materiais da indenização jamais deverá se prender ao valor indenizável, enquanto objeto da ação em particular, mas sim às informações inerentes à morosidade daquela prestação jurisdicional pretendida, as quais devam se mostrar idôneas a autorizar a classificação do feito dentre aqueles que, pelo excessivo e inescusável tempo de tramitação, possam constituir objeto de responsabilização extracontratual do Estado por eventuais danos daí decorrentes.

Em um primeiro momento, pode-se ter a impressão de que o magistrado estaria a exercer um poder discricionário por demais amplo, e que em função disso este passaria a praticar um papel legislativo que não lhe é próprio.

Contudo, Suzana de Toledo Barros (2003, p. 176) ensina que, pela comparação dos casos julgados, analogias seriam possibilitadas e que, aos poucos, "pautas de valorações de bens diante de casos concretos" iriam se formando, e que assim ocorreria tipificação de "muitas situações de colisão de direitos, de maneira a não se poder generalizar acerca de uma constante flutuação de resultados de ponderações em face de uma total liberdade do juiz".

Persistindo nesse raciocínio, pode-se esperar que a jurisprudência a ser firmada com a aplicação deste particular direito fundamental, ou seja, ao relativo à razoável duração do processo, vá, aos poucos, dissipando a névoa que o envolve e demarcando pontos que servirão de parâmetros seguros ao julgamento da razoabilidade de sua imediata aplicação. Basta, para tanto, que esta aplicação imediata se dê, invariavelmente, naqueles casos 
extremos, para os quais nenhum argumento de justificativa da demora seja aceitável - à luz das ponderações recomendadas pelo princípio da proporcionalidade, e que esta gama de casos iniciais da espécie seja ampliada na medida do possível. Este seria, salvo melhor juízo, o começo da eficácia do novo direito fundamental à razoável duração do processo.

\subsection{Das excludentes da responsabilidade do Estado}

Uma vez demonstrado o liame causal existente entre a demora na efetivação da prestação jurisdicional e o dano sofrido pelo jurisdicionado, dever-se-ia surgir imediatamente para o Estado, por força do § 60 do Art. 37 e do inciso LXXVIII combinado com o $\S 1$ 을 do Art. 5ํ, ambos da Constituição Federal, a obrigação de indenizar àquele que tenha suportado o dano, independentemente da cogitação de culpa - em sentido amplo do Poder Público, sopesadas, obviamente, as limitações técnicas e materiais analisadas quando do estudo da aplicabilidade do direito fundamental à luz do princípio da proporcionalidade. Esta é a responsabilidade objetiva do Estado.

É necessário ressaltar, contudo, que na aplicação imediata do direito fundamental à razoável duração do processo, como embasamento legal em decisões que condenem o Estado a indenizar eventuais danos decorrentes da delonga da prestação jurisdicional, dos diversos fatores que poderiam eventualmente explicar ou querer justificar a razão da demora no trâmite dos processos judiciais, tais como: complexidade do processo, problemas relacionados às deficiências estruturais do Judiciário (quadros de pessoal reduzidos frente ao crescente número de ações, equipamentos obsoletos, instalações inadequadas, etc), culpa da vítima, culpa de terceiro, motivos de força maior, caso fortuito, estado de necessidade, ou, ainda, as "infindáveis" possibilidades de recursos - atribuídas a uma legislação processual que demanda alterações focadas na utilidade do processo - nem todos, obviamente, seriam idôneos para fundamentar decisão denegatória da responsabilidade do Estado.

Do rol enumerado no parágrafo imediatamente anterior, José Augusto Delgado (2005, p. N-O) e Lair da Silva Loureiro Filho (2005, p. 231) são uníssonos ao entenderem que somente a culpa da vítima (exclusiva ou concorrente), a força maior, o estado de necessidade e a culpa de terceiro constituiriam hipóteses admissíveis de exclusão da responsabilidade estatal. 


\section{Conclusão}

O acesso à justiça é um direito subjetivo fundamental que somente se vê realizado com a efetiva entrega da prestação jurisdicional. Tal efetividade traduz-se na obtenção pelo jurisdicionado dos efeitos práticos do provimento jurisdicional pleiteado, ou seja, o recebimento do bem da vida de direito, em tempo que se entenda moderado e justo.

A despeito do vago significado do termo "razoável" - empregado no inciso LXXVIII do Art. 5o da Lei Maior -, entende-se que o direito fundamental à razoável duração do processo deverá ter - por força do $\S 1$ 으 do citado artigo - aplicabilidade imediata, independentemente de lei infraconstitucional que venha fixar possíveis parâmetros de razoabilidade.

Muito embora a jurisprudência venha se revelando de forma refratária ao reconhecimento da responsabilidade do Estado por atividade judiciária, mormente quanto aos danos decorrentes da morosidade crônica verificada na tramitação dos processos, forçoso é reconhecer que o ordenamento jurídico positivado não dá margem a tal denegação (Art. 37, § 6으, da Constituição Federal), conforme o entendimento da doutrina dominante, já que dizer o direito ao caso concreto é atribuição exclusiva do Poder Público, e, em não o fazendo em tempo razoável, verifica-se a perfeita caracterização da responsabilidade por omissão.

Sendo assim, todo e qualquer jurisdicionado que tenha sofrido dano em decorrência da demasiada e inescusável demora na prestação jurisdicional poderá demonstrar o liame causal e requerer, em juízo, a condenação do Estado à correspondente indenização.

O magistrado deverá servir-se do princípio da proporcionalidade para decidir quanto à razoabilidade das indenizações da espécie, frente aos demais direitos fundamentais que também clamam por eficácia, já que as possibilidades orçamentárias do Estado apresentam-se com alcance limitado.

$\mathrm{Na}$ análise concernente ao nexo causal, deve o juiz, ainda, atentar para as excludentes de responsabilidade do Estado (culpa da vítima; culpa de terceiro; força maior; e estado de necessidade), para que não se corra o risco de colocar o Estado na posição de segurador universal, o que poderia torná-lo insolvente ou, ao menos, impossibilitá-lo de 
realizar os demais direitos fundamentais expressados no texto constitucional, aos quais também se deve dar a máxima eficácia possível.

Vislumbra-se, então, com base nas premissas consignadas nesta conclusão que, malgrado o reconhecimento das dificuldades que certamente acompanharão o início da respectiva aplicação, há possibilidade palpável de se dar efetividade imediata ao direito fundamental à razoável duração do processo.

Basta, para tanto, que se comece com pequenos passos, como, por exemplo, a condenação do Estado a arcar com as indenizações devidas a todos os jurisdicionados que tenham demonstrado, de forma inequívoca, o nexo causal entre o dano sofrido e a delonga processual grave e inescusável, nos casos cuja classificação da morosidade situe-se naquela faixa na qual o tempo de tramitação tenha ultrapassado todos os parâmetros do senso comum da razoabilidade, independentemente do valor indenizável, mas exclusivamente em função do retardamento do trâmite, e após as imprescindíveis ponderações recomendadas pelo princípio da proporcionalidade.

\section{Referências}

AGRA, Walber de Moura. Manual de Direito Constitucional. São Paulo: RT, 2002.

AMARAL JÚNIOR, José Levi Mello do. Demagogia constitucional? A celeridade virou direito mas nada o garante. Consultor Jurídico, fev. 2005. Disponível em : <http://conjur.com.br>. Acesso em: 26 jan. 2006.

BARROS, Suzana de Toledo. O princípio da proporcionalidade e o controle de constitucionalidade das leis restritivas de direitos fundamentais. 3. ed. Brasília: Brasília Jurídica, 2003.

BARROSO, Luís Roberto. Temas de direito constitucional. 2. ed. Rio de Janeiro: Renovar, 2002.

BASTOS, Celso Ribeiro. Curso de Direito Administrativo. 5. ed. São Paulo: Saraiva, 2001.

BOBBIO, Norberto. Teoria do Ordenamento Jurídico. 10. ed. Brasília: Unb, 1999.

BONAVIDES, Paulo. A Constituição aberta. 2. ed. São Paulo: Malheiros, 2004. 
. Curso de Direito Constitucional. 10. ed. São Paulo: Malheiros, 2000.

CANOTILHO, José Joaquim Gomes. Direito Constitucional e Teoria da Constituição. 7. ed. Coimbra: Almedina, 2003.

CÓDIGO CIVIL. Organização dos textos, notas remissivas e índices por Juarez de Oliveira. 41. ed. São Paulo: Saraiva, 1991.

DELGADO, José Augusto. A demora na entrega da prestação jurisdicional. Responsabilidade do Estado. Indenização. TRF 5a Região. Disponível em:

<http://www.jfrn.gov.br/docs/especial21.doc>. Acesso em: 15 dez. 2005.

DI PIETRO, Maria Sylvia Zanella. Direito administrativo. 18. ed. São Paulo: Atlas, 2005.

FELIPPE, Donaldo J. Dicionário jurídico de bolso. 16. ed. Campinas, SP: Millennium, 2004.

FERRARI, Regina Maria Macedo Nery. Normas constitucionais programáticas: normatividade, operatividade e efetividade. São Paulo: RT, 2001.

FERREIRA FILHO, Manoel Gonçalves. Curso de Direito Constitucional. 18. ed. rev. e atual. São Paulo: Saraiva, 1990.

GASPARINI, Diógenes. Direito administrativo. 4. ed. rev. e ampl. São Paulo: Saraiva, 1995.

GUERRA FILHO, Willis Santiago. Teoria Processual da Constituição. 2. ed. São Paulo: Celso Bastos Editor: Instituto Brasileiro de Direito Constitucional, 2000.

HESSE, Konrad. A força normativa da Constituição. Porto Alegre: Sergio Antonio Fabris Editor, 1991.

HOLANDA FERREIRA, Aurélio Buarque. Novo dicionário da Língua Portuguesa. 2. ed. rev. e aum. Rio de Janeiro: Nova Fronteira, 1986.

JUCOVSKY, Vera Lúcia R. S. Responsabilidade civil do Estado pela demora na prestação jurisdicional: Brasil - Portugal. São Paulo: J. de Oliveira, 1999.

LAZZARINI, Álvaro. Estudos de Direito Administrativo. 2. ed. São Paulo: RT, 1999.

LOUREIRO FILHO, Lair da Silva. Responsabilidade pública por atividade judiciária. São Paulo: RT, 2005. 
MEDAUAR, Odete. Direito administrativo moderno. 8. ed. rev. e atual. São Paulo: RT, 2004.

MEIRELLES, Hely Lopes. Direito Administrativo Brasileiro. 29. ed. atual. São Paulo: Malheiros, 2004.

MELLO, Celso Antônio Bandeira de. Curso de Direito Administrativo. 19. ed. rev. e atual. São Paulo: Malheiros, 2005.

MENDONÇA, Fabiano André de Souza. Limites da responsabilidade do Estado. Rio de Janeiro: Impetus, 2003.

MODESTO, Paulo. Responsabilidade do Estado pela demora na prestação jurisdicional. Revista Diálogo Jurídico, Salvador, CAJ - Centro de Atualização Jurídica, v. 1, n. 1, abr. 2001. Disponível em: <http://www.direitopublico.com.br>. Acesso em: 12 nov. 2005.

SOARES JÚNIOR, Dário José. O processo como instituição no Estado pós-moderno. Jus Navigandi, Teresina, a. 6, n. 52, nov. 2001. Disponível em:

<http://jus2.uol.com.br/doutrina/texto.asp?id=2440>. Acesso em: 05 fev. 2006.

STF - RE 369.820-6/RS - Segunda Turma - Relator Ministro Carlos Velloso - DJ de 27.02.2004-p. 38.

STF - RE 372.472-0/RN - Segunda Turma - Relator Ministro Carlos Velloso - DJ de 28.11.2003- p. 33.

STRECK, Lenio Luiz. Hermenêutica jurídica e $(m)$ crise - uma exploração hermenêutica da construção do Direito. 5. ed. rev. atual. Porto Alegre: Livraria do Advogado Editora, 2004.

TAVARES, André Ramos. Argüição de descumprimento de preceito fundamental: análises à luz da Lei n. 9.882/99. São Paulo: Atlas, 2001.

TEIXEIRA, Sálvio de Figueiredo et alli. O Judiciário e a Constituição. São Paulo: Saraiva, 1994. XAVIER, Márcio Coelho. Fundamentos da responsabilidade civil estatal. Brasília: OAB, 2005. 
